\title{
A physical environmental management perspective on municipal water supply: proposals for Tlokwe City Council
}

\author{
ERIC NEALER AND KISHOR RAGA*
}

\begin{abstract}
All South Africans, especially, those involved with the development and management of its water resources should be aware that South Africa is generally an arid to semi-arid region, with an average rainfall of approximately $500 \mathrm{~mm}$ per annum, compared to a world average of $860 \mathrm{~mm}$. Consequently, potable water is a very scarce resource, and is often the biggest prohibiting factor for development of, for example, new residential areas in a town or city.

Hence a public service rendering municipality like the Tlokwe (Potchefstroom) City Council will have to, in its quest to manage its potable water supply more effectively, efficiently and economically, take cognisance of aspects such as:

The origin of its potable water;

The nature and extent of the storage and treatment of the potable water;

The manner in which the potable water is distributed to the users and consumers; and

The manner in which the wastewater is collected, treated and managed.

The authors of this article are of the opinion that the aforementioned can only be taken care of effectively by incorporating a physical environmental management perspective in its municipal governance.

Keywords: Diversity and complexity, Environmental management, Municipal governance, Tlokwe City Council, Potable water, Topo-cadastral, topographic and geohydrological information, Water catchment area, Water supply management, Water supply related legislation.
\end{abstract}

Disciplines: Public Management, Public Administration, Geography, Development Studies, History, Environmental Studies, Town Planning.

\section{Intoduction}

All South Africans, especially, those involved with the development and

Dr Eric Nealer (E-mail: eric.nealer@nwu.ac.za) is Subject Head of Public Management and Governance, School for Social and Government Studies, NorthWest University. Dr Kishor Raga (E-mail: kishore.rage@nmmu.ac.za) is principal lecturer in Public Management at Nelson Mandela Metropolitan University, Port Elizabeth. 
management of its water resources should be aware that South Africa is generally an arid to semi-arid region, with an average rainfall of approximately $500 \mathrm{~mm}$ per annum, compared to a world average of $860 \mathrm{~mm}$. Furthermore, the rainfall is unevenly distributed, with 65 per cent of the country's surface area receiving less than $500 \mathrm{~mm}$ per annum of which 21 per cent of the area receive less than $200 \mathrm{~mm}$. Of the mentioned 'fallen rain' only 10 per cent reaches the rivers which constitute the country's crucial potable water resource. Not only do they accumulate, contain and convey the surface runoff of rain, but the surface waters and ground water are intimately interrelated. Ground water may eventually, via fountains, reach the rivers on the surface or even flow from underground water compartments in underground rivers and seepages (Fuggle \& Rabie, 2005:647). The result is that potable water is a scarce resource, and often the biggest limiting factor for development of inter alia, new residential areas in a town or city.

The ever-increasing demand for potable water by the country's consumers, industry and agriculture in future will have to be addressed and considered in a more pro-active, committed and effective manner by the major public policy makers and implementers. A concerted effort will have to be made to upgrade the basic water supply services to, especially, the rural population in the democratic South Africa. Concurrently, the quality of the available surface- and groundwater resources is deteriorating due to, inter alia, over utilisation of water resources, uncontrolled urbanisation, devegetation and pollution by amongst others, mines and farmers. The shortage of suitably trained, skilled and experienced municipal staff in the complex public management field of the supply, treatment and purification of water at the municipal sphere is the biggest cause of water contamination (Jordan \& Klein, 2008:1).

As the sole custodian of South Africa's potable water resources, the Department of Water Affairs and Forestry (DWAF) has been proactive in establishing research and management procedures to protect the country's water resources. The National Water Act, 36 of 1998 attempts to ensure that the nature and extent of the management of rainfall catchment areas, river basins and groundwater resources are managed in a sustainable and integrated way. DWAF understands the golden rule for the effective, efficient and economical management of freshwater ecosystems such as rivers in that the conditions, water quality and biota of any body of freshwater are the product and reflection of events and conditions in its catchment' (Fuggle \& Rabie, 2005:277).

In view of the aforementioned the Tlokwe City Council (formerly known as Potchefstroom Local Municipality), a Category B municipality, will in its quest to manage its potable water supply more effectively, efficiently and economically, have to take cognisance of aspects such as the origin, transport, storage, treatment 
and distribution of its potable water. The authors of this article are, therefore of the opinion that the aforementioned can only be achieved effectively by following a physical environmental management approach. That is, to be sensitive to and take careful cognisance of, and to manage the aggregate of surrounding objects, conditions, and factors that influence the life and habits of man or any other organism or collection of organisms' (South Africa, 1989). The human environment 'would comprise the external circumstances, conditions, and factors that affect the existence and development of an individual or group'. In the context of development and conservation, this 'would consist of both a source of materials for creating things that will improve the human condition, and a source of natural amenities and life-support systems which directly contribute to human well-being and survival' (Council for the Environment, 1989). In this article, the regulating legislature, existing infrastructure and the nature and extent of the physical (natural and man-changed) environment of a typical Category B municipality is highlighted for the incorporation of an effective management sensitiveness for the larger environment regarding the origin, acquisition and management of its potable water supply. Several logical conclusions and recommendations will be presented to cultivate an environment conducive to the creation of water management knowledge on the local government sphere of South Africa.

\section{Legislative aspects}

The most relevant and significant pieces of legislation are listed below. Their identification is a prerequisite for the proper investigation of the nature and extent of the physical environment within which for example, the City Council of Tlokwe (Potchefstroom) attempts to manage its potable water.

\subsection{Constitution}

The Constitution of the Republic of South Africa Act, 108 of 1996, (Constitution) arranges the so-called 'social contract' between the South African Government and the country's citizens by structuring the three spheres of the governmental legislature (national, provincial and local) and the execution of its public policies. The government is morally obliged to be sensitive to, to identify, and in earnest take notice of the unlimited needs of the country's citizens. Through effective prioritisation the Government is expected to determine which issues should be addressed through effective and efficient public administration and management in an attempt to add value to the respective communities and the country's society as a whole (South 
Africa, 1996).

\subsection{Other significant legislation}

The following Acts also add to the innovative changes brought about regarding the local governance and delivery of public services on the local government sphere of a developing South Africa:

- National Water Act, 36 of 1998: which attempts to ensure that the nation's water resources are protected, used, developed, conserved, managed and controlled in a sustainable manner, for the benefit of all;

- National Environmental Management Act, 107 of 1998: which attempts to provide for co-operative environmental governance by establishing principles for decision-making on matters affecting the environment, institutions that will promote cooperative governance and procedures for co-ordinating environmental functions exercised by organs of state, to provide for certain aspects of the administration and enforcement of other environmental management laws, and to provide for matters connected therewith;

- The Municipal Structures Act, 117 of 1998: which establishes strong city governments with geographical boundaries that generally encompass the functional region of the major urban centres and also try to promote new relationships with communities through mechanisms such as ward committees and sub-councils;

- The Municipal Systems Act, 32 of 2000: which tries to modernise municipal administration and establish a new relationship between government and the citizens in line with the overall governance ethos;

- The Water Services Act, 108 of 1997, and regulatory additions of 2001: with clear regulations relating to compulsory national standards and measures to conserve water;

- The Municipal Finance Management Act, 56 of 2003: which attempts to improve corporate governance and financial management practice; and the

- Intergovernmental Relations Framework Act, 13 of 2005: which attempts to provide within the principle of cooperative government, a framework for the three government spheres, and all organs of state within these governments, and to facilitate coordination in the implementation of public policy and legislation.

\section{Place and role of a municipality}

A municipality is that part of the government which manifests at 


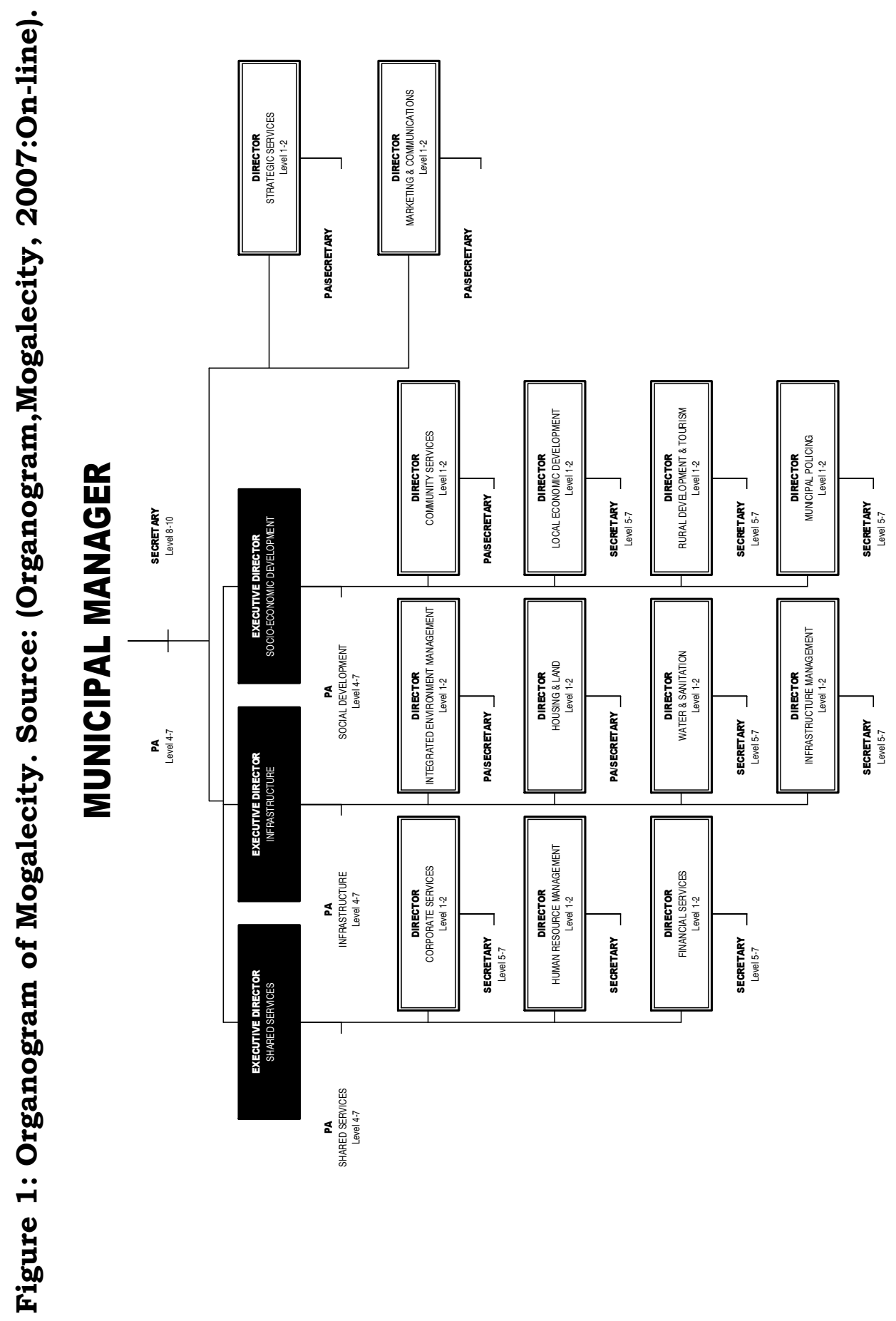

TD, 4(1), July 2008, pp. 157-173. 
grassroots level and exists as a legal person, as well as a key part of a set of governmental relationships and organisational systems. A municipality is required to give effect to the provisions of the Constitution and priority to the basic needs of the local community which it is expected to serve, promote the development of the local community, and ensure that all members thereof have access to at least the minimum level of basic municipal services (Craythorne, 2006:159). In the developing South African context the following categories of municipalities are identified:

- Category A municipalities (metropolitan municipalities) (e.g. City of Tshwane Metropolitan Municipality);

- Category B local municipalities (e.g. Polokwane Local Municipality); and

- Category C district municipalities (e.g. Capricorn District Municipality of which the Polokwane Local Municipality forms a part).

The following presentation gives some indication of the manner in which a well-structured municipality's organisational structure is established in attempting to address the fundamental needs of its respective communities with limited resources and in accordance with its Integrated Development Plan (IDP):

\section{Figure 1: Organogram of Mogalecity. Source: (Organogram,Mogalecity, 2007:On-lin}

Please refer to page 161

From the aforementioned it can be inferred that the functions that a municipality is expected to render are of a diverse and complex nature. The concept diversity encompasses various forms of heterogeneity which the public sector institution must attempt to accommodate in the different services it has to deliver and the subsequent workforce it has to organise and manage (Nel et al., 2001:395). Complexity on the other hand is indicative of the degree of sophistication and specialisation contained in the execution of a specific activity. It is partly a function of societal heterogeneity, confronting managers with a public that have varying resources, needs and expectations, and partly of structural diversity within and among more or less autonomous organisations whose activities must be co-ordinated in many instances through service networks (Fox \& Meyer, 1995:24).

In the next section the most important physical environmental aspects with reference to the municipal management of potable water supply to a Category B local municipality - City Council of Tlokwe 
(Potchefstroom) will be analysed.

\section{Physical environmental aspects and potable water management}

The general external environment is everything which exists beyond an institution's (e.g. a municipality) demarcated boundary area of judicial responsibility. The trends emanating from it, often sensed through the specific environment, consistently exert their influences on a public sector institution. Public resource managers should devise instruments to identify and manage them accordingly (Schwella et al., 1999:18-19). External influences from the general environment regarding the place (structure) and role (functions) of a municipality such as the City Council of Tlokwe include inter alia, aspects such as nature, politics, economy, culture, and technology. In this article only the influence of the natural (physical) environment will be highlighted.

One of the most crucial functions of every municipality in South Africa is the sustainable delivery (import, storage, treatment, distribution and collection of the wastewater) of potable water services to all its customers within a municipality's area of responsibility. In a national sample survey in South Africa by the Human Sciences Research Council (HSRC) in 1998, 41 per cent of the respondents placed crime prevention at the top of their needs agenda to improve the quality of life for all. The creation of jobs was listed as a second need and the provision of improved services was identified as the third important priority. Of these public services the respondents identified the provision of running water (27 per cent) as the most crucial basic need, then came affordable housing (20 per cent), while the provision of electricity and health care respectively came in at 16 per cent (Khosa, 2000:248-249).

In a large municipality, the department responsible for water and scientific services usually has to look after the provisioning of a constant supply of safe potable water and related water supply services to all the water users and consumers in the specific municipal area. Specific functions of such an organisational unit might include the management and control of potable water, wastewater operations and services, the governance of water regulations, planning, tariff setting, and the construction of minor water related municipal works (Durban, 2006:On-line).

In order to manage the supply of potable water in an effective, efficient and economic manner, the successful municipal manager and his subordinate municipal officials as well as the responsible political office bearers of a municipality should ensure that 
amongst other, the physical environmental aspects discussed in the sections 4.1 to 4.4 hereunder are continuously taken into account.

\subsection{Topo-cadastral information}

Topo-cadastral environmental information is indicated on 1:250000 scale topo-cadastral maps surveyed and published by the Surveyor-General, Chief Directorate: Surveys and Mapping of the Department of Land Affairs. It covers aspects such as the locality of towns, roads, railway lines, land-use, boundaries (international, provincial and municipal), rivers, dams, contour lines, and registered topo-cadastral farms. Municipal managers and leading officials, developers and the citizens should keep abreast and be informed of the nature, extent and impacts of these aspects. For example, can a major national road leading through a town indicate the possibility of traffic congestions due to slow traffic movement and abnormal load carrying motor trucks. The presence and location of a railway line through a city can result in specific residential area development locations and road infrastructure (roads, bridges and storm water canals) patterns. The land-use aspect will be indicative of the historical migration and settlement patterns of the people in the area. The location of dams and marshes and flow of rivers can have direct environmental implications on land-use and possible water use and soil pollution. The nature and extent of the wire fencing of the registered topo-cadastral farms can contribute to the demarcation of, for example, a municipality's area of jurisdiction. See Map 1 hereunder for some crucial topocadastral information of the Potchefstroom municipal area.

If one zooms in on the 1:250000 topo-cadastral map of the Potchefstroom municipal area, it is possible to observe the following interesting facts:

- The Mooi River rises at Bovenste Oog in the Mathopestad area north of the Klerkskraal Dam, while the main waters of the Wonderfonteinspruit (becoming the Mooiriverloop $\pm 8 \mathrm{~km}$ northeast of Carletonville on the farm Oog van Wonderfontein) originate around the gold mine residue deposits of several old and abandoned mines of the West Rand Consolidated Gold Mine Company, south of Krugersdorp and east of Randfontein (the single largest impact on the water quantity and quality of the Mooi River catchment) (Riedel, 2003:1).

- The Mooi River flows further south from the Klerkskraal Dam where it is joined by the Mooiriverloop on the Du Toits Spruit and Kiel farms. Approximately $7 \mathrm{~km}$ south from this point, the Mooi River flows into the Boskop Dam which is situated $\pm 12 \mathrm{~km}$ north of 
Map 1: Topo-cadastral map of the Potchefstroom municipal area. Source: (Department of Land Affairs, 2006).

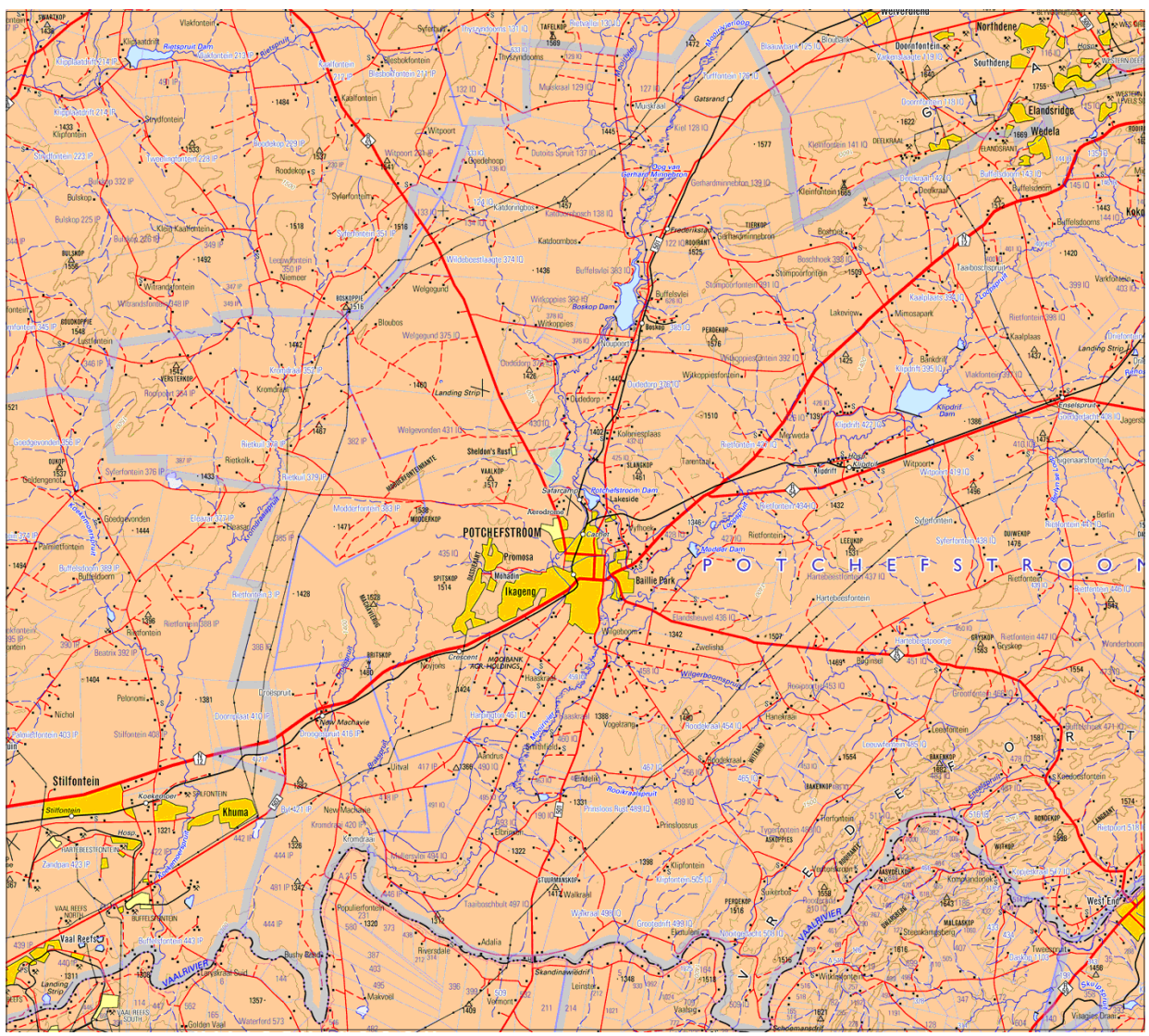

Potchefstroom. The Boskop Dam is further fed with underground water from the Gerhard Minnebron Eye which is situated $\pm 5 \mathrm{~km}$ north of the dam on the Gerhardminnebron farm. The Boskop Dam area is a proclaimed nature reserve and accessible to fishermen, campers and for daily picnicking. There are sufficient toilet facilities and ablution blocks but there is no electricity.

- Immediately north of the City, there is another much smaller Potchefstroom Dam (Lakeside dam). From there the Mooi River flows south for $\pm 9 \mathrm{~km}$ where it is joined by the Loopspruit from the north-east (with the Klipdrif Dam $\pm 26 \mathrm{~km}$ upstream). The Spitskopspruit and Vaalkopspruit rise from the western side of the City and flow into the Wasgoedspruit. The last mentioned is seriously polluted with phosphates, nitrates, ammonia and fluorides due to a fertilizer factory upstream that was dismantled in 2006 (Nell, 15 February 2008). The Wasgoedspruit splits the 
City into a northern and southern area before it joins the Mooi River. The Mooi River then continues southwards with inputs from Potchefstroom's storm water (including waste water) and treated sewage effluent from the Tlokwe City Council's wastewater treatment works at the southern entrance (Viljoenskroon road) to the City. It then flows $\pm 25 \mathrm{~km}$ in a south-western direction where it joins the Vaal River on the Kromdraai farm (northern bank) and the Hoogekraal farm (southern bank).

- Potchefstroom's potable water is supplied from the water of the Boskop Dam. From the Dam, the City's potable water flows southwards primarily via two concrete canals (Boskop right bank and left bank canals) from where the water is directed to the Tlokwe City Council's water purification works $\pm 800 \mathrm{~m}$ west of the Potchefstroom Dam. At this plant the water is purified and then pumped into various water reservoirs in the City from where the potable water is fed into the water supply pipeline network to the consumers (Liebenberg, 18 March 2008).

- There is extensive agricultural farming (cattle, vegetables, pigs, chickens etc) taking place along the Mooi River.

- The following gold mines are identified in the immediate vicinity of the City:

- Deelkraal ( $\pm 34 \mathrm{~km}$ north-east of Potchefstroom)

- Welverdiend ( $\pm 37 \mathrm{~km}$ north-north-east of Potchefstroom)

- Doornfontein ( $\pm 42 \mathrm{~km}$ north-east of Potchefstroom)

- Stilfontein ( $\pm 34 \mathrm{~km}$ west-south-west of Potchefstroom)

- Buffelsfontein ( $\pm 33 \mathrm{~km}$ south-west of Potchefstroom)

- Diamond diggings can be identified along the Mooi River and on the De Beers Kraal, Rysmierbult, Rietvallei, Muiskraal and Rooidraai farms.

- The geographical border of Potchefstroom's municipality had been demarcated according to the magisterial districts in place on February 1998. These magisterial districts are demarcated according to the farm boundaries (wire fences) of the topocadastral registered farms. It is clear from the Municipality's geographical area of jurisdiction that it is administratively tasked with a vast area in which it must attempt to manage its municipal jurisdiction and basic services.

\subsection{Topographical information}

Adding to the aforementioned environmental information, an 
investigation of a municipal area such as the Tlokwe City Council (Potchefstroom), enables one to also identify some topographical information of importance to the City's macro-planners, developers and citizens. This form of information is indicated on 1:50000 scale topographical maps surveyed and published by the Surveyor-General, Chief Directorate: Surveys and Mapping of the Department of Land Affairs.

Aspects such as the locality of surrounding towns, roads, railway lines, land-use (cultivated land, townships, industries, and mines), rivers, dams, canals, marshes, height above mean sea level contour lines, and registered topo-cadastral farms with its boundaries can be clearly perceived by a novice reader. The Council for Geoscience, Department of Minerals and Energy also publishes maps with geological information from which one can determine the nature and extent of the surface and underground rock types and younger geological features and intrusions such as dolerite dykes, and faults. See Map 2 below for some crucial topographical information on the Potchefstroom municipal area.

\section{Map 2: Topographical map of the Potchefstroom area. Source: (Department of Land Affairs, 1995).}

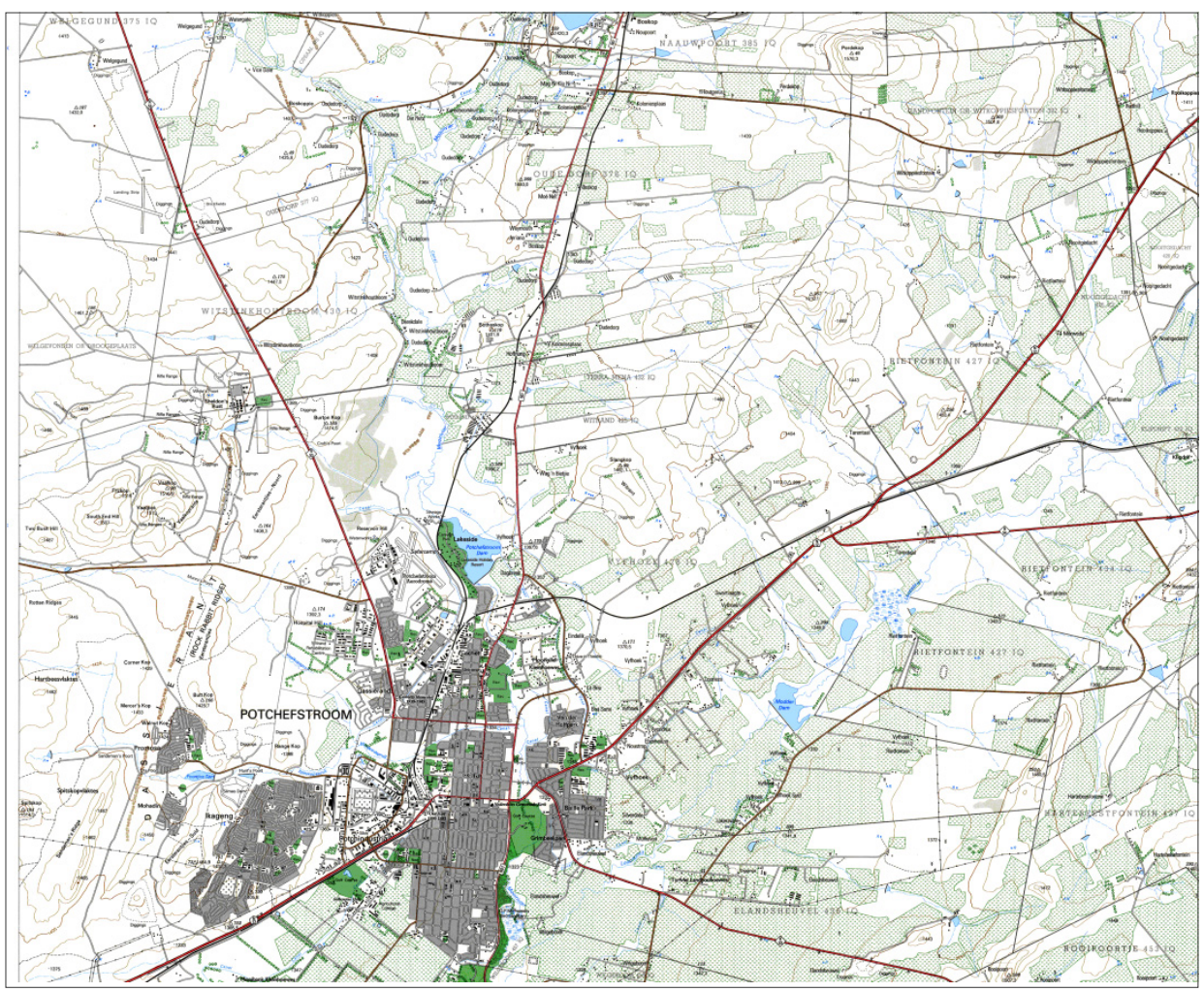


From the aforementioned topo-cadastral and topographical information as well as newspaper reports on the Wonderfonteinspruit and Mooi River catchment areas, one can for example understand the concern of the inhabitants of Potchefstroom and its surrounding area on the potential dangers of pollution of their potable water resources by unregulated farming and mining in the water catchment area of the Mooi River (Van Heerden, 14 December 2007; Tempelhoff, 1 Maart 2008:5; Jordan \& Klein, February 3, 2008:1). More attention will be given to this aspect in the following section.

\subsection{Geo-hydrological information}

This form of information covers aspects such as the nature and extent of the surface- and underground water, surface water drainage and the water catchment areas of the Mooi River, Wonderfonteinspruit and Loopspruit. These geo-hydrological aspects are (if not, they should be) of concern to the managers and senior leading officials, political office bearers and citizens of the Tlokwe City Council regarding the management of their potable water supply.

Map 3: Geo-hydrological map of the Potchefstroom area. Source: (GPM Consultants, 2007).

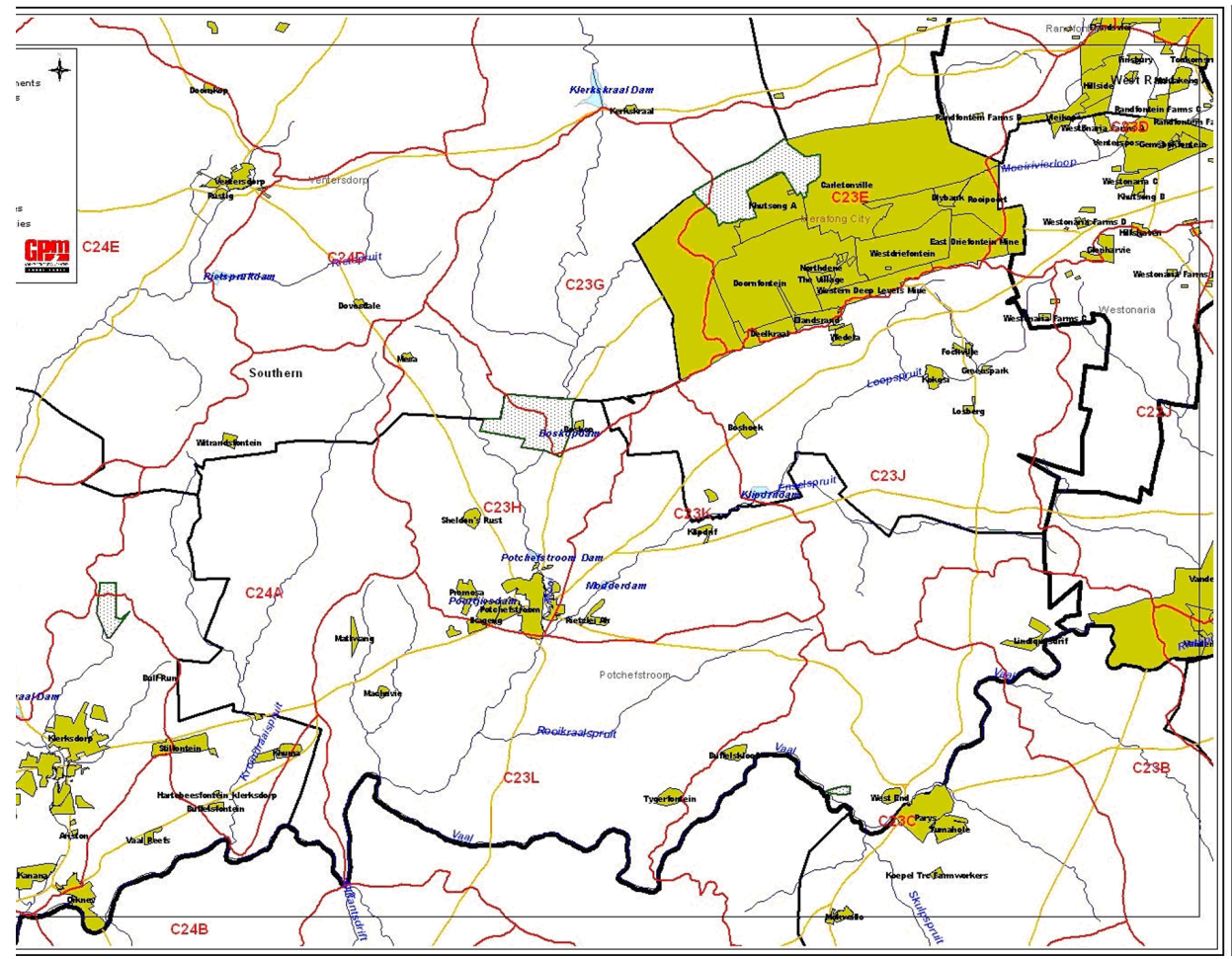


From Map 3 one can determine that the surface water of the Mooi River as well as the Wonderfonteinspruit rise in geo-hydrological catchment areas starting up to $80 \mathrm{~km}$ north of Potchefstroom and it flows through areas in which the underground geology (dolomite), surface soil types, mining and human interventions have a direct influence on the nature and extent of the water's quantity and quality which have to be used and consumed by other down-stream clients. The water catchment area of a river is the area from which it receives surface and underground water (e.g. the quaternary Mooi River catchment area number $\mathrm{C} 23 \mathrm{H}$ north of Potchefstroom). It is separated from an adjacent water catchment area by a natural watershed which is presented by a topographically high area relative to surrounding areas (DWAF, 2006[a]). Bates and Jackson (1987:732) define a watershed as the specific point on land (ground surface) from where falling water can flow in two opposite directions.

The fact that the municipal government jurisdictions of South Africa (demarcated according to magisterial districts which are mostly constructed according to registered topo-cadastral farm boundaries) do not correspond with the demarcated surface water (rivers) drainage regions' boundaries, could lead to ineffective, inefficient and noneconomical municipal management of water, sanitation and environmental services (Fuggle \& Rabie, 2005:315).

\subsection{Additional general physical environmental aspects}

In addition to the forms of environmental information discussed above, a municipality like the Tlokwe City Council, must also keep the following general physical environmental aspects in mind in order to facilitate and manage an effective, efficient and economical potable water supply system:

- Environmental sensitivity towards and effective protection of the natural environment through the numerous environmental laws which might be best achieved if all the available environmental conservation control and law enforcement mechanisms are fully utilised and all persons willing to participate in the enforcement process are allowed to do so (Loots in SAJELP, 1994:34);

- The possible dangers of pollution by farmers, industries, citizens, and mines in the Mooi River up-stream of Potchefstroom must be identified through thorough geo-hydrological surveys and managed;

- The Tlokwe City Council must ensure that they, through effective management of the potable water supply, and the waste- and stormwater, do not pollute the down-stream section of the Mooi River towards the Vaal River; 
- The Boskop- and Potchefstroom dams as the primary water reservoirs of Potchefstroom's potable water should be managed, protected and developed as such;

- Conjunctive use of both surface (rivers) and underground (boreholes) water should be investigated and implemented by the Tlokwe City Council. Underground water which is exposed to less evaporation, is often of better quality (naturally pre-filtered) and provides a slow release of water to a cyclical surface water supply (DWAF, $2006[\mathrm{~b}]$ );

- Citizens should be informed about their rights and obligations with reference to the use and conservation of potable water. Continuous participation should also be encouraged by means of optimum access and transparency whenever local government issues are debated and decided upon;

- Optimal transparency and access to public service delivery information as well as the nature and extent of new macrochallenges facing a municipality and its citizens should be continuously communicated with all the role-players and stakeholders involved;

- Effective communication media with other municipalities, citizens, advisors and influential politicians and individuals must be developed and maintained;

- The committed, involved and experienced citizens should be encouraged to serve as informal contacts and advisors regarding more complex public service delivery activities such as the dangers of pollution to a town's / city's drinking water;

- "Brown- and black-outs" in electricity supply to especially the various potable water, waste water and effluent pump stations as well as the implementation of "slow-down" in potable water supply should be managed in a more effective, efficient and economical manner;

- The public service delivery infrastructure of a municipality should be maintained, developed, expanded, constructed and managed in a proactive, effective, efficient and economical way;

- The public managers and leading/supervisory officials of the local government sphere institutions must be trained more effectively on the place and role of the wider physical and man-changed environment and especially be equipped with more effective communication skills and the willingness to listen, look, learn and plan ahead;

- With reference to the handling of river floods and droughts a municipality should have updated disaster-risk management 
plans in place and communicate them to the citizens; and

- Other more advanced geographical, geo-hydrological and information technological measures inter alia GISs, river flow computer modelling, 1:10 000 ortho photo's, and satellite images should be researched and utilised to inculcate a butterfly view of a town's / city's primary natural environment determinants of the municipal management of its potable water supply.

\section{Conclusion}

With reference to the municipal management of potable water supply the typical Category B municipality finds itself responsible for the execution of a highly complex function in a very dynamic and highly regulated environment. In addition, the nature and extent of the physical environment is also very difficult to manage effectively, efficiently and economically. It therefore calls for the leading municipal officials, managers and committed political office bearers to be equipped with specific knowledge of the physical environment (to be informed of and understand the big picture) and to use geographical mapping tools in order to improve their long term planning skills. In their quest for more management knowledge and skills the effective use, interpretation and development of geographical and cartographical tools as well as modern information technology might result in more effective water supply management and local governance in general.

\section{List of sources}

ACTS SEE SOUTH AFRICA.

BATES, R.L. \& JACKSON, J.A. 1987. Glossary of geology. Virginia: American Geological Institute.

COUNCIL FOR THE ENVIRONMENT. 1989. Integrated environmental management in South Africa. Pretoria: Government Printer.

CRAYTHORNE, D.L. 2006. Municipal Administration: The Handbook. Cape Town: Juta \& Co.

DURBAN. 2006. Water and Sanitation Services website. http:// www.durban.gov.za/e The kwini/Services / water_and_sanitation/about. Date of access: 10 November 2006.

DEPARTMENT OF LAND AFFAIRS. 1995. 1:50 000 Topographical map 2627CA Potchefstroom. Cape Town: Government Printer.

DEPARTMENT OF LAND AFFAIRS. 2006. 1:250 000 Topo-cadastral 
map 2626 Wes-Rand. Cape Town: Government Printer.

DEPARTMENT OF WATER AFFAIRS AND FORESTRY (DWAF). 2006[a]. A guideline for the Assessment, Planning and Management of Groundwater Resources within Dolomitic Areas in South Africa. Pretoria: DWAF.

DEPARTMENT OF WATER AFFAIRS AND FORESTRY (DWAF). 2006[b]. Guidelines for Water Supply Systems Operation and Management Plans During Normal and Drought Conditions. Pretoria: DWAF.

FOX, W \& MEYER, I.H. 1995. Public Administration Dictionary. Cape Town: Juta \& Co,Ltd.

FUGGLE, R.F. \& RABIE, M.A. 2005. Environmental management in South Africa. Cape Town: Juta \& Co,Ltd.

GPM Consultants. 2007. Map 3: Geo-hydrological map of the Potchefstroom area. Polokwane.

JORDAN, B\& KLEIN, M. 2008. Now it's a water crisis. Business Times:1, 3 February.

KHOSA, M. 2000. Empowerment through service delivery. Pretoria: Human Sciences Research Council.

LIEBENBERG, W., Area Manager, Upper-Vaal: Potchefstroom Area Office of the Gauteng Region, Department of Water Affairs and Forestry, Potchefstroom. Personal interview. (18 March 2008), Potchefstroom.

MOGALE CITY. 2006. Organogram. http://www.mogalecity.gov.za/ municipality/vision.stm. Date of access: 3 January 2007.

NEL, P.S., GERBER, P.D., VAN DYK, P.S., HAASBROEK, G.D., SCHULTZ, H.B., SONO, T, \& WERNER, A. 2001. Human Resources Management. Cape Town: Oxford University Press Southern Africa.

NELL, B., Chief Chemist, Tlokwe City Council (Potchefstroom). Personal interview. (15 February 2008). Potchefstroom.

RIEDEL, K. 2003. The establishment of a catchment management plan for the Mooi

River (Kromdraai) catchment, North West Province, South Africa. M.Sc. dissertation (Unpublished manuscript). Pretoria: University of Pretoria.

SACN (South African Cities Network). 2006. State of the Cities Report 2006. Braamfontein: SACN.

SAJELP (South African Journal of Environmental Law). 1994. Making 
environmental law effective. SAJELP, Vol 1 No 1.

SCHWELLA, E., BURGER, J., FOX, W. \& MüLLER, J.J. 1999. Public Resource Management. Kenwyn: Juta \& Co,Ltd.

SOUTH AFRICA. 1989. Environment Conservation Act 73 of 1989. Pretoria: Government Printer.

SOUTH AFRICA. 1996. Constitution of the Republic of South Africa Act 108 of 1996. Pretoria: Government Printer.

SOUTH AFRICA. 1998. National Water Act 36 of 1998. Pretoria: Government Printer.

SOUTH AFRICA. 1998. National Environmental Management Act 107 of 1998. Pretoria: Government Printer.

TEMPELHOFF, E. 2008. Damwater gevaarlik vir kinders, sê dié mense. Naweek-Beeld: 5, 1 Maart.

VAN HEERDEN, D. 2007. Experts say water is safe, for now. Potchefstroom Herald: 14 December. 